\title{
Divisão celular: modelização em Genética e Biologia Molecular
}

\author{
Cell division: modeling in Genetics and Molecular Biology \\ División celular: modelado en Genética y Biología Molecular
}

Recebido: 23/12/2021 | Revisado: 30/12/2021 | Aceito: 07/01/2022 | Publicado: 10/01/2022

\author{
Henrique Mendes da Silva \\ ORCID: https://orcid.org/0000-0001-6878-1622 \\ Universidade de Brasília, Brasil \\ E-mail: henriquemendes_bio@hotmail.com
}

\begin{abstract}
Resumo
O ensino de genética e biologia molecular realizado na escola ainda é um método de ensino tradicional, baseado em conteúdo, quase sempre distante da realidade dos estudantes, não sendo utilizados recursos e métodos diferenciados para a implementação da sala de aula. A pesquisa teve como objetivo analisar o potencial didático que as representações externas podem desempenhar no ensino e aprendizagem de "Divisão Celular" por meio de uma oficina pedagógica, para isso optou-se em desenvolver um método simples, barato e prático com a utilização de modelo didático em uma aula de Biologia ao ensino de mitose e meiose para estudantes do Ensino Médio, contribuindo para o estudo e aprofundamento da estrutura dos cromossomos, além dos comportamentos do mesmo durante a mitose e meiose. Assim, foi realizada uma aula prática com estudantes do $3^{\circ}$ ano da Escola Estadual Carolina Silva localizada na cidade de Vazante/MG, com intuito de observar a contribuição desta metodologia no processo de ensinoaprendizagem. O levantamento de dados é baseado em pesquisa bibliográfica, portais de livros e periódicos, incluindo publicações relacionadas a este tema de pesquisa em contextos nacionais e internacionais, além da coleta de relatos e observação participante. Os dados indicam que a construção de modelos didáticos pode ser considerada uma ferramenta eficaz para a conexão ensino-aprendizagem, e se constitui em um processo representativo, utilizando o desenvolvimento do modelo tridimensional de estruturas genômicas. Esses modelos são recursos acessíveis que podem aumentar a compreensão dos tópicos de genética e reduzir o nível de abstração por meio do aprendizado tátil.

Palavras-chave: Educação; Ensino médio; Genética; Modelos didáticos.
\end{abstract}

\begin{abstract}
The teaching of genetics and molecular biology carried out at school is still a traditional content-based teaching method, which is often far from the reality of students, and different resources and methods are not used for the implementation of the classroom. The research aimed to analyze the didactic potential that external representations can play in the teaching and learning of "Cell Division" through a pedagogical workshop. For this, it was decided to develop a simple, cheap and practical method using a model didactic in a Biology class to teaching mitosis and meiosis to high school students, contributing to the study and deepening of the structure of chromosomes, in addition to its behavior during mitosis and meiosis. Thus, a practical class was held with students from the 3rd year of the Carolina Silva State School located in the city of Vazante/MG, in order to observe the contribution of this methodology in the teaching-learning process. Data collection is based on bibliographic research, book portals and periodicals, including publications related to this research topic in national and international contexts, in addition to the collection of reports and participant observation. The data indicate that the construction of didactic models can be considered an effective tool for the teaching-learning connection, and constitutes a representative process, using the development of a three-dimensional model of genomic structures. These models are accessible resources that can increase understanding of genetics topics and reduce the level of abstraction through tactile learning.
\end{abstract}

Keywords: Education; High school; Genetics; Didactic models.

\section{Resumen}

La enseñanza de la genética y la biología molecular que se lleva a cabo en la escuela sigue siendo un método de enseñanza tradicional basado en contenidos, que muchas veces se aleja de la realidad de los estudiantes, y no se utilizan diferentes recursos y métodos para la implementación del aula. La investigación tuvo como objetivo analizar el potencial didáctico que las representaciones externas pueden jugar en la enseñanza y el aprendizaje de la "División Celular" a través de un taller pedagógico. Para ello, se decidió desarrollar un método sencillo, económico y práctico utilizando un modelo didáctico en una Biología. clase para enseñar mitosis y meiosis a estudiantes de secundaria, contribuyendo al estudio y profundización de la estructura de los cromosomas, además de su comportamiento durante la mitosis y meiosis. Así, se realizó una clase práctica con alumnos de $3^{\circ}$ año de la Escuela Estatal Carolina Silva ubicada en la ciudad de Vazante / MG, con el fin de observar el aporte de esta metodología en el proceso de enseñanza-aprendizaje. La recolección de datos se basa en la investigación bibliográfica, portales de libros y revistas, 
incluyendo publicaciones relacionadas con este tema de investigación en contextos nacionales e internacionales, además de la recolección de informes y observación participante. Los datos indican que la construcción de modelos didácticos puede considerarse una herramienta eficaz para la conexión enseñanza-aprendizaje, y constituye un proceso representativo, utilizando el desarrollo de un modelo tridimensional de estructuras genómicas. Estos modelos son recursos accesibles que pueden aumentar la comprensión de temas de genética y reducir el nivel de abstracción a través del aprendizaje táctil.

Palabras clave: Educación; Escuela secundaria; Genética; Modelos didácticos.

\section{Introdução}

O ensino e a aprendizagem de ciências implicam no entendimento de fenômenos moleculares e a produção de associações conceituais entre os níveis simbólicos, macroscópicos e microscópicos, em especial no ensino de Genética (Rundgren, Yao, 2014). Genética é uma área da ciência que possui aplicações em muitos campos, contudo, o ensino desse conteúdo nem sempre tem sido enriquecido de práticas de aprendizagem bem-sucedidas (Broman et al., 2011; Varghese et al., 2012).

Uma das grandes adversidades de ensinar e possibilitar o aprendizado do estudante em relação a determinados conceitos de Genética é a grande complexidade e a imposição de abstração necessária para assimilar esses conteúdos, que escapam a uma aproximação sensorial direta, isto é, às suas vivências experimentadas no cotidiano (Silva, 2021). Em razão da necessidade que a aprendizagem dos conceitos impõe, essa tem sido agente de muitos estudos e análises do que ocorre em circunstâncias escolares, como em atividades que se sucedem extraclasse (Brito, 2018).

O Ensino de Genética envolve a interligação de conteúdos e a associação de cálculos com acontecimentos cotidianos. Para essa finalidade, o professor necessita lançar mão de diferentes metodologias para que sua exposição seja compreendida (Krasilchik, 2004). Segundo Giordan e Vecchi (1996, p. 9), "felizmente, o problema da transmissão dos conhecimentos está, enfim, exposto à plena luz do dia”. Mesmo após 20 anos da publicação desse livro, essa dificuldade ainda é perceptível. Os autores supracitados salientam (p. 9) "que a maior parte do saber científico, ensinado durante a escolaridade, é esquecido após alguns anos, algumas semanas até [...], se é que foi realmente adquirido alguma vez".

A construção de conhecimento dos conceitos de Genética pelos estudantes vem tornando-se objeto de muito estudo. Dessa forma, muitas pesquisas têm sido executadas com esse mesmo propósito (Leach, Wood-Robinson, 2000; Lopes, Silva, 2018; Duré, Andrade, Abílio, 2018; Silva, 2021). Nesse cenário, Brito (1996) salienta que uma das atuações da escola é o ensino de denominações, visto que é aceita a concepção de que é por meio da construção dessas que o estudante conseguirá aprender as fundamentações e alcançará autonomia para resolver problemas que o envolvam. Consequentemente, é importante que o Ensino de Genética seja produzido em um entendimento que vá além da fixação por memorização de conceitos e beneficie a conjuntura em que o estudante está inserido. Nesse sentido, a Base Nacional Comum Curricular (BNCC) propõe:

[...] a superação da fragmentação radicalmente disciplinar do conhecimento, o estímulo à sua aplicação na vida real, a importância do contexto para dar sentido ao que se aprende e o protagonismo do estudante em sua aprendizagem e na construção de seu projeto de vida (BRASIL, 2018, p. 15).

Sendo assim, nesta pesquisa, optou-se, como material didático, os modelos didáticos para colaborar no desenvolvimento dos conceitos fundamentais referentes ao conteúdo de Genética, com o intuito de tornar mais eficiente a sistematização do conhecimento, tendo em vista a coerência de pré-requisitos com que os estudante chegam à terceira série do Ensino Médio. A preferência pelo material deve-se em virtude de se ajustar corretamente à realidade da escola na qual foi realizada a pesquisa.

Essa oficina surgiu ao refletir sobre a dificuldade dos estudantes em entender todo o mecanismo de divisão celular que abrange desde as mudanças morfológicas (condensação cromatínica, rearranjo do citoesqueleto e das organelas, fragmentação 
do envoltório nuclear), até eventos quantitativos do material genético (replicação do DNA, manutenção ou redução de ploidia, separação dos pares de cromossomos homólogos ou das cromátides irmãs), bem como os demais processos que caracterizam cada etapa do ciclo celular.

Assim, a proposta aqui exposta foi de unificar ludicidade e criatividade, resultando num ensino dinâmico e contextualizado de divisão celular em formato de oficina. Dentro da conjuntura apresentada, esta pesquisa teve por objetivo analisar o potencial didático que as representações externas podem desempenhar no ensino e aprendizagem de "Divisão Celular" por meio de uma oficina pedagógica. Essa contextura é importante por dois motivos: (i) o ensino de Genética tem sido descrito com problemas referentes ao processo de ensino e aprendizagem e (ii) estudantes manifestam dificuldades com conceitos relacionados ao ensino de Genética. Presume-se que tratar dessas temáticas possa colaborar para o aumento da aplicação pedagógica eficaz de modelos didáticos nas salas de aula de ciências.

A pesquisa teve como objetivo analisar o potencial didático que as representações externas podem desempenhar no ensino e aprendizagem de "Divisão Celular" por meio de uma oficina pedagógica, para isso optou-se em desenvolver um método simples, barato e prático com a utilização de modelo didático em uma aula de Biologia ao ensino de mitose e meiose para estudantes do Ensino Médio, contribuindo para o estudo e aprofundamento da estrutura dos cromossomos, além dos comportamentos do mesmo durante a mitose e meiose. Além disso, a fim de observarmos se com esta atividade prática o processo de ensino-aprendizagem é favorecido e a construção de conhecimento se torna mais satisfatória.

\section{Procedimentos Metodológicos}

Em concordância com Silva (2021), as práticas com materiais concretos são fundamentais para o estabelecimento de um ensino e aprendizagem significativo e envolvente, visto que esses materiais contribuem para que os estudantes construam o conhecimento dos processos e fenômenos que estão em discussão. A busca por metodologias significativas para o aprendizado de Biologia, sobretudo de Genética, pelos estudantes é trabalhosa, portanto, a aplicação de materiais concretos mostra-se um potencial enorme que colabora com o processo de ensino e aprendizagem.

Para Jean Piaget (1975), uma excelente pedagogia é aquela que possibilita circunstâncias para que o estudante possa experimentar até alcançar as conclusões: manusear objetos, criar, recriar, descobrir, redescobrir, buscar respostas de seus questionamentos, argumentar, correlacionar novas informações e conhecimentos a partir de suas vivências, promovendo, dessa maneira, uma ressignificação dos saberes.

Segundo Gil (2010), a metodologia é o percurso, no qual o pesquisador emprega-se de métodos para atingir seus objetivos, partindo de um problema a ser solucionado, sendo a condição necessária para a competência científica. A pesquisa, portanto, é um procedimento formal, com método de pensamento reflexivo, que requer um tratamento científico e se constitui no caminho para conhecer a realidade ou para descobrir verdades parciais (Marconi; Lakatos, 2003).

A pesquisa realizada teve uma abordagem bibliográfica com produção de material didático. A pesquisa de revisão bibliográfica tem como objetivo recuperar o conhecimento científico acumulado sobre um problema. De acordo com Botelho et al (2011), O processo de revisão da literatura requer a elaboração de uma síntese pautada em diferentes tópicos, capazes de criar uma ampla compreensão sobre o conhecimento. Neste sentido, a revisão da literatura aqui proposta foi o primeiro passo para a construção dos resultados, possibilitando a elaboração de modelos didáticos mais adequados ao ensino desta ciência na educação básica.

A presente pesquisa foi desenvolvida no município de Vazante-MG e voltada aos estudantes do $3^{\circ}$ ano da Escola Estadual Carolina Silva. Nesta pesquisa, foi proposta a construção de dois modelos didáticos, com uso de matérias de baixo custo. Os modelos foram as estruturas dos cromossomos e os processos de mitose e meiose. A oficina foi organizada para 
ensinar os estudantes de ensino médio sobre Divisão Celular, ou seja, Mitose e Meiose, através de construção de modelos didáticos representando as fases de cada divisão celular. Tais modelos buscaram ajudar no entendimento dessas divisões celulares, bem como das mudanças cromossômicas (numéricas e estruturais) e outras características do DNA.

A aplicação foi executada durante o semestre de 2019/2, compreendendo dois encontros presenciais de 100 minutos cada. Posteriormente, o professor regente de aulas trabalhou a temática em aula expositiva teórica. Toda a elaboração da atividade cumpriu as pressuposições propostas por Mayer (2003).

Para confecção dos modelos didáticos, foi oferecido e utilizado um kit de material de baixo custo, sendo massa de modelar, papel cartão e color set, cola, EVA, canetas hidrográficas de várias cores, caixas de pizza, papelão, giz de cera e lápis para colorir (Figura 1). Durante toda atividade, foi dada liberdade aos estudante para que construíssem as estruturas celulares da forma que achassem pertinente.

O segundo momento teve início com questionamentos sobre o tema, feitos pelo professor, com o intuito de recordar os conceitos trabalhados na aula anterior. Em seguida, logo após as orientações iniciais, para a execução da oficina, os estudantes se organizaram em grupos e separaram os materiais para confeccionar as fases das divisões celulares de acordo com suas preferencias e que simulassem o processo de divisão de forma livre, sem consulta a materiais didáticos impressos e digitais.

Figura 1: Kit de materiais recebidos pelos grupos na oficina.

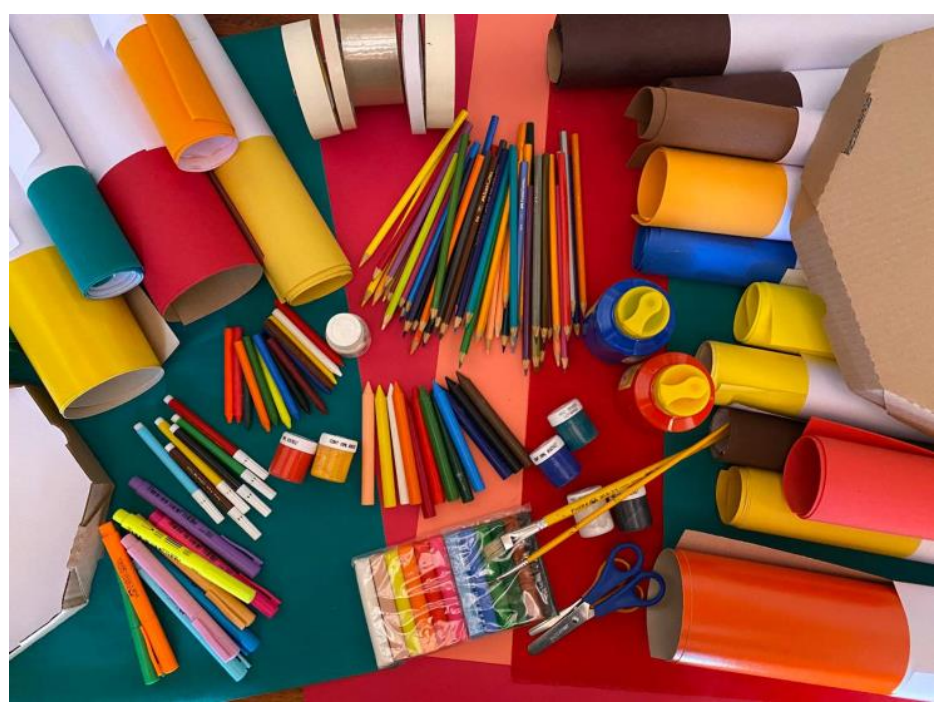

Fonte: Autor (2021).

Em virtude da praticidade dos materiais utilizados para a construção dos modelos didáticos, foi possível trabalhar o conceito de replicação do DNA na fase $\mathrm{S}$ da interfase do ciclo celular e, por consequência, a representação dos cromossomos. Os meterias permitiram, ainda, trabalhar a diversidade de cromossomos (metacêntricos, submetacêntrico, acrocêntrico ou telocêntrico). Devido à pluralidade de cores dos materiais, a permuta foi representada atentando-se à diferença de origem materna e paterna das moléculas homólogas (pelas cores) e correspondência entre os materiais genéticos.

Após comunicarem que haviam finalizado a etapa da oficina, o pesquisador convidou os estudantes a participarem de uma roda de conversa. Todos os participantes participaram das discursões. A análise de avaliação de aplicabilidade da oficina de modelos didáticos foi executada a partir de dois aspectos: a ótica do pesquisador e a ótica dos estudantes. Para o relato de observação participante, a metodologia de análise de conteúdo foi embasada a partir de Bardin (2011). Como forma de manter o anonimato dos estudantes, seu nome foi substituído pela letra (E) seguido por um número, exemplo: E. 25. 
Por meio da utilização do material didático manipulável (material concreto) no estudo de genética, além de possibilitar aulas de Biologia mais interessantes e prazerosas, buscou-se, também, a melhor assimilação do conteúdo por parte dos estudantes, com finalidade de melhorar os processos de ensino e aprendizagem.

\section{Pressupostos Teóricos}

\subsection{Ensino de Genética}

Nos últimos anos, vivenciamos e percebemos, através dos meios de comunicação, notícias do imenso avanço científico no campo da Genética, essa ciência extremamente heterogênea e abrangente. Com base nessas pesquisas, linhas de estudos foram se fortalecendo, como, por exemplo, a genética médica, a biorremediação, a biotecnologia, a terapia gênica, o aconselhamento genético, o melhoramento genético de espécies animais e vegetais, a preservação de espécies silvestres ameaçadas de extinção, a taxonomia molecular de animais e de microrganismos, a genética forense, a toxicogenética, a epigenética, a epidemiologia genética, organismos geneticamente modificados, clonagem, entre outros (Silva, 2021).

Constantemente, notamos que temáticas relacionadas a essa ciência apresentam-se incorporadas ao cotidiano da sociedade contemporânea e transformam-se em manchetes jornalísticas, o que, certamente, reflete-se na sala de aula, em especial no ensino médio. $\mathrm{Na}$ atualidade, não somos capazes e nem podemos mais tratar os temas relacionados à Genética apenas abordando os experimentos de Gregor Mendel com suas ervilhas. Seguindo Francisco (2005, p. 10), "negar a relação existente entre a ciência, a tecnologia e a sociedade, é negar, por conseguinte, a nossa própria forma de viver e pensar o mundo". A sociedade contemporânea demanda uma nova ótica para questões dos processos educacionais e, nesse sentido, a escola deve estar alinhada às novas metodologias. De acordo com a Base Nacional Comum Curricular (BNCC):

No novo cenário mundial, reconhecer-se em seu contexto histórico e cultural, comunicar-se, ser criativo, analíticocrítico, participativo, aberto ao novo, colaborativo, resiliente, produtivo e responsável requer muito mais do que o acúmulo de informações. Requer o desenvolvimento de competências para aprender a aprender, saber lidar com a informação cada vez mais disponível, atuar com discernimento e responsabilidade nos contextos das culturas digitais, aplicar conhecimento para resolver problemas, ter autonomia para tomar decisões, ser proativo para identificar os dados de uma situação e buscar soluções, conviver e aprender com as diferenças e as diversidades (Brasil, 2018, p.14).

Mesmo que os estudantes evidenciem interesse por temáticas ligadas à Genética, eles demostram uma ampla dificuldade no aprendizado dos conceitos, o que dificulta a compreensão da grande parte dos processos biológicos (SILVA, 2021). Temp e Bartholomei (2018) salientam que os estudantes trazem concepções advindas, principalmente, da mídia, pelas relações entre amigos e familiares, e que essas perspectivas, muitas vezes deturpadas, atrapalham o aprendizado. KlautauGuimarães et al. (2008) salientam que identificar esses conceitos errôneos vinculados à Genética é de extrema importância para que ocorra o aprendizado mais eficaz e permanente de temáticas relacionadas a essa ciência. Goldback (2008) destaca que ensinar e divulgar Genética é tão necessário quanto trabalhoso.

Da perspectiva dos estudantes, os conteúdos de Genética referentes ao material genético, seus processos de transmissão, transformações e interatividade são os mais importantes, porém, em contrapartida, são os mais complexos de serem aprendidos. Tais adversidades se devem à carência de aplicabilidade e à demanda de abstração que esses conceitos necessitam (Mello; Carmo, 2009).

Nesse cenário, Justina e Ferla (2006) apontam que, para se posicionar diante dos questionamentos providos pelos avanços científicos e tecnológicos da genética, os estudantes precisam de uma base de conhecimento, que deve ser trabalhada na escola, através da educação científica. Para tal, são importantes fatores que proporcionam a efetiva aprendizagem de 
ciências na educação básica, com a sistematização dos conteúdos ocorrendo de forma multifacetada, contribuindo para uma aprendizagem que tenha mais significações.

“[...] nesse sentido, tomando como pontos de partida, não só a importância de se considerar os conhecimentos prévios ao conhecimento científico que os estudantes carregam consigo e suas implicações na formação de conceitos, como também o fato de considerarmos primordial que o professor desenvolva consciência sobre a pluralidade de significados que um conceito a ser ensinado pode adquirir" (BRITO 2018, p. 19).

A escola permanece como o primordial meio onde os estudantes têm oportunidade de acesso à aprendizagem organizada e sistematizada através dos conceitos científicos, com olhar sobre a posse de um conhecimento mais consistente, significativo e produtivo que passa a ser utilizado no cotidiano em uma concepção cidadã (Cid, Neto, 2005). Os autores supracitados, apesar disso, ressaltam que só "esse tipo de conhecimento poderá permitir aos alunos, enquanto futuros cidadãos de pleno direito, tirarem proveito da informação veiculada diariamente pelos meios de comunicação" (p. 1).

Segundo Melo e Carmo (2009),

“[...] a análise dos conhecimentos e da compreensão da Genética por parte dos jovens estudantes vem sendo muito investigada, assim como pesquisas têm sido realizadas com esse objetivo, atentando para a percepção de problemas propostos que envolvam o uso de novas tecnologias genéticas, em contextos variados, em questões suscitadas nessa área do conhecimento biológico" (p. 595).

Cid e Neto (2005) indicam que a compreensão dessas dificuldades e de suas circunstâncias pode estabelecer um fator necessário para que o professor possa ser capacitado para construir, planejar e expor as temáticas de maneira ajustada às aptidões e interesses do estudante.

Podemos, aqui, apresentar pesquisas sobre o ensino de Genética de importância internacional, e outras de expressão nacional, como os estudos de Stewart (1982), Bugallo (1995), Bannet e Ayuso (1995), Bahar e Johnstone (1999), Ayuso e Bannet (2002), Pedrancini et al. (2007), Ladelfo et al. (2012), Franzolin e Bizzo (2012), Giacoia et al. (2014), Temp e Bartholomei (2018), Silva (2021). Além disso, a temática específica "Ensino de Genética e afins" está aplicada em uma fração importante dos estudos defendidos em programas de pós-graduação, no Brasil, no intervalo de 1972 a 2004, e no âmbito de ensino de Biologia. As principais temáticas levantadas nas dissertações e teses abrangem o ensino da hereditariedade, com suas implicações citológicas, genéticas, moleculares, evolutivas, além de suas abordagens biotecnológicas e bases éticas (Sardinha, 2009).

Temp e Bartholomei (2018, p. 88) pesquisaram como os professores de Biologia conceituam aprendizagem em Genética: "para os professores, aprender Genética se relaciona com questões cotidianas, relacionar Genética com conteúdos de outras séries e a capacidade de abstrair e compreender a relação do DNA com o funcionamento celular e a expressão do fenótipo". As autoras supramencionadas salientam que os professores pesquisados têm uma ótica de aprendizagem que se distancia de um modelo tradicional apenas conteudista associado à memorização de conceitos. Uma das formas de iniciar as transformações no Ensino de Genética é relacionar ao conteúdo aprendido componentes da cultura e da vivência do cotidiano dos estudantes, da escola e da comunidade. Dessa forma, não limita a abrangência do conhecimento tratado; ao contrário, dá significado ao aprendizado, assegurando um diálogo legítimo.

É necessário considerarmos que, mesmo diante de todas essas dificuldades, os estudantes levam consigo uma soma de conhecimentos culturais prévios que necessitam ser trabalhados em sala de aula. É indispensável que haja uma adequação do conhecimento com qualidade, procurando assegurar um suporte teórico-prático sólido. Para a BNCC (2018, p 463), “em lugar de pretender que os estudantes apenas aprendam o que já sabemos, o mundo deve lhes ser apresentado como campo aberto 
para investigação e intervenção quanto a seus aspectos sociais, produtivos, ambientais e culturais". Solicitados a dialogar sobre seus pontos de vista para elucidar determinados acontecimentos e compará-los com outras explicações, os estudantes podem compreender as deficiências de suas ideias e a importância de complementá-las com outras informações, portanto, construindo um processo que se firma no dinamismo e ressignificação. Nesse contexto, o professor pode interferir de modo a fazer com que o estudante reconheça a relação entre os inúmeros processos explicativos para um mesmo grupo de eventos e fenômenos (Delizoicov et al., 2002).

O ensino de Biologia proporciona o encontro entre o estudante com diversos conceitos e, por muitas vezes, há um confronto entre esses conceitos e as concepções elaboradas pelo senso comum acerca desses fenômenos biológicos (Silveira, 2008).

Silveira (2008) destaca que o professor, nessa perspectiva, deve identificar-se como um moderador que pode propiciar circunstâncias para que o estudante desenvolva seu repertório de ideias no campo conceitual por intermédio de estratégias mentais, em ordenação gradativa de complexidade. São essas conjunturas que darão significado aos conceitos. Quanto mais contextualizados forem apresentados pelos professores, mais significativo se transformarão os conceitos para os estudantes.

Por esse ângulo, Cid e Neto (2005, p. 4) elaboraram algumas diretrizes para o Ensino de Genética:

- "Diagnóstico das ideias prévias dos alunos e utilização de esquemas para a resolução de problemas que explicitem os mecanismos de resolução e a sua relação com conceitos."

- "Apresentação dos princípios e dos conceitos da genética de forma a serem óbvias as relações entre os conceitos, nomeadamente entre as estruturas básicas - célula, núcleo, cromossomo, gene, DNA."

- "Explicitação da relação entre os processos - mitose - meiose e fecundação - os ciclos da vida e continuidade da informação genética".

- "Abordagem dos conceitos, do simples para o complexo: à medida que os alunos vão dominando os conteúdos, a sua formulação deve tornar-se mais complexa, apresentando problemas divergentes, proporcionando a formulação de hipóteses alternativas."

- "Iniciação dos problemas com situações simples e de interesse para os alunos, promovendo coleta de dados."

- "Apresentação de problemas destinados a que os alunos aprendam o algoritmo (exercício), mas também problemas autênticos que impliquem, entre outras tarefas, analisar dados, emitir hipóteses explicativas ou interpretar resultados."

- "Clarificação da passagem do macronível para o micronível, de tal forma que os alunos sejam capazes de ver os conceitos como parte de um todo".

\subsection{Modelos Didáticos no Ensino de Genética}

O sistema de ensino tradicionalista tem sua visão no conteúdo, caracterizando-se pela ênfase nos métodos de transmissão cultural. O ensino na Educação Básica é pautado na transferência da cultura vigente, sem levar em consideração a conjuntura social da comunidade escolar e os anseios dos estudantes (Predebon, Del Pino, 2009).

A metodologia evidencia a memorização de informações, fórmulas, processos, denominações e conhecimentos de forma fragmentada, em que os estudantes ocupam um local passivo na aquisição dos conceitos e processos transmitidos pelo professor em seus métodos de ensino-aprendizagem. A forma com que são avaliados considera a memorização dos conceitos difundidos e acontece por meio de provas e exames (Campos et al., 2008).

Na procura de transformações frente ao modelo tradicionalista de ensino, a aplicação de ferramentas como modelos didáticos, segundo Setúval e Bejarano (2010), representam recursos atraentes e que podem ser adequados na prática docente em termos de abordagem de conteúdos que necessitam de maior assimilação pelos estudantes, em particular no que se refere ao Ensino de Biologia. Nesse campo, e em especial na área da Genética, é percebida dificuldade em trabalhar alguns conteúdos de maneira mais ampla e sem relação com o cotidiano do estudante. 
Os modelos didáticos são muito utilizados na Biologia, pois essa área abrange muitos conceitos, teorias, processos, fenômenos e hipóteses (Vygotsky, 2003), limitando, dessa forma, o nível de abstração em sala de aula e fazendo com que a escola "escape" daquilo que é visto como tradicional.

O professor, ao optar por modelos didáticos como instrumento pedagógico, tem a oportunidade de trabalhar o raciocínio e a interação entre os estudantes, proporcionando o exercício da liberdade intelectual de forma lúdica. Além disso, se associado a outras atividades práticas pedagógicas, podem ser também uma grande ferramenta de educação inclusiva, no ensino de pessoas com algum tipo de necessidade especial (Pereira, 2019).

A integração de modelos didáticos no procedimento de ensino e aprendizagem pode ser uma das formas de produzir a ressignificação das concepções e dos conteúdos (Justina, Ferla, 2006). Pavan (1998) salienta que é necessário a utilização de instrumentos para possibilitar o processo de aprendizagem do conteúdo de maneira mais efetiva e dinâmica, pois empregar esses meios propicia uma melhora na assimilação do conteúdo pelo estudante. Barros e Belmiro (2017) demostram que, por serem de complexa compreensão, nos processos empregados no ensino de Genética, o professor tem potencialidade de aplicar práticas que auxiliem nos procedimentos de construção do conhecimento. Dessa forma, práticas variadas de ensino que abrangem modelos, arte e jogos mostram-se como eficientes durante o agir pedagógico.

A incorporação de novas metodologias educacionais é necessária, uma vez que, geralmente, as aulas de Ciências e Biologia são essencialmente informativas e expositivas, o que propicia o não progresso de competências fundamentais para o estudante, como, por exemplo, observação, argumentação, levantamento de hipóteses, tomada de decisões e inferências (Lucchini, 2009).

Levando em consideração os estímulos e as preferências dos estudantes em inter-relacionar-se e expressar-se, as práticas lúdicas, como modelos didáticos, têm potencialidade de serem ótimas metodologias de integralizar entusiasmo ao conhecimento, uma vez que essas ferramentas contribuem no estimulo do prazer sobre o conteúdo e os processos a ser ensinado (Campos et al., 2009).

Os modelos didáticos possibilitam ao estudante ser o agente promotor do seu próprio processo de ensinoaprendizagem, de acordo com o descrito por Ausubel (1980). Por meio deles, aprender significativamente é resultado da reestruturação e desenvolvimento de ideias prévias na estrutura mental e na habilidade de confrontar e conectar novos conteúdos.

É de competência do professor estimular as potencialidades dos estudantes, contribuindo para que o lúdico favoreça a aprendizagem significativa dos processos que estejam sendo trabalhados. No entanto, é necessário estar atento ao que expressa Luckesi (2014, p. 15): “de fato, por si, uma atividade não é lúdica nem 'não-lúdica'. Pode ser, ou não, a depender do estado de ânimo de quem está participando, assim como da circunstância em que participa da atividade”. Na opinião do autor supracitado, a atividade lúdica é uma condição interna e não é semelhante para todos, desse modo, algumas atividades poderão ser desinteressantes para alguns, mas atraentes para outros.

Campos et al. (2008) salientam que os métodos de inovação que compreendem os modelos didáticos, maquetes e jogos são promissores de serem utilizados no ensino. Essa colocação fortalece o que Corrêa e Silva Júnior (2010) reforçaram ao levarmos em consideração que, para reduzir as dificuldades no ensino de Genética, a metodologia lúdica pode atingir mais espaço como instrumento dos professores no ambiente escolar.

Analisada a indispensabilidade de mudanças no ensino de Biologia, sobretudo no ensino de Genética, as atividades lúdicas têm potencial como práticas aptas a proporcionar o raciocínio científico, procurando o desenvolvimento intelectual do estudante e da conjuntura do ensino-aprendizagem (Cabrera, 2007).

O professor deve estimular os estudantes para que eles desenvolvam as atividades propostas e, para tal, é indispensável o entendimento de uma correlação entre o conteúdo e eventos cotidianos (Barni, 2010). Barros e Belmiro (2017) 
revelam que a aplicação de materiais didáticos é eficiente para promover a criatividade do estudante por meio da promoção de habilidades cognitivas. Segundo Ferreira e Justi (2005), o estudante configura-se protagonista do processo de construção do conhecimento a partir do instante em que ocorre o engajamento em atividades que estimulam um raciocínio crítico sobre a temática em discursão.

$\mathrm{Na}$ atualidade, faz-se indispensável a aplicação de recursos didáticos que beneficiem o processo de ensinoaprendizagem e, especialmente, estimulem a curiosidade dos estudantes. Diversas são as pesquisas que dão destaque às atividades práticas como uma relevante ferramenta de ensino. Manprim (2007) observou, em seu trabalho, que os professores tinham entendimento da necessidade das práticas experimentais nas aulas de Biologia, revelando que esse ensino possibilita circunstâncias para que o estudante possa reconhecer processos de aprendizagem que associam sua relação com o que está ocorrendo no seu dia a dia, estabelecendo uma ligação entre a teoria e a prática.

O uso de modelos didáticos mostra-se de baixo custo, tornando-se opções acessíveis de aquisição e manuseio, além de serem capazes de estimular o processo das relações socioemocionais (Jann, Leite, 2010). Para Jann e Leite, além dos benefícios já mencionados, a aplicação de modelos didáticos auxilia a solucionar problemas como a falta de interesse e a falta de recursos. Além disso, potencializam habilidades cognitivas necessárias, por intermédio da solução de problemas, assimilação, criatividade e raciocínio, associado à ampliação de competências que proporcionam a maturidade do estudante e a construção do conhecimento.

Podemos mencionar alguns pesquisadores que caracterizam os modelos didáticos aplicados em sala de aula como instrumentos de engajamento, acréscimo e assimilação de conteúdos, entre eles, Tarouco et al. (2004), Martinez et al. (2008), Neves e Neves (2016) e Pereira (2019). Existem, ainda, as publicações da revista Genética na Escola, que incluem uma seção intitulada "Material Didático". Essa seção tem o propósito de difundir ferramentas inéditas que sejam capazes de proporcionar aprendizagens tanto de conteúdos teóricos, abstratos e conceituais quanto de conteúdos procedimentais e atitudinais.

À frente das pesquisas acadêmicas apontadas, verifica-se que é imprescindível incluir metodologias didáticas diversas no ensino de Genética e suas aplicações, deixando de lado o modelo tradicional dos métodos fragmentados (BELMIRO, BARROS, 2007). Os autores apontam, ainda, que o ensino de Genética por meio da prática e seus conteúdos e processos intrínsecos têm potencialidade de oportunizar aos estudantes competências imprescindíveis para fortalecer uma atitude crítica sobre os eventos e fenômenos do cotidiano. Porém, o simples fato de inserção do modelo didático como ferramenta metodológica não assegura a aprendizagem. Para tal, ele necessita ser planejado, pensado e educativo (Pedro, 2009). Zanon et al., (2008) salienta que um modelo didático só pode ser conhecido como educativo se propiciar o desenvolvimento de habilidades cognitivas, como a criatividade, raciocínio e resolução de problemas.

As estratégias que utilizam os modelos didáticos tornam o estudante ativo na construção do próprio conhecimento. A construção do modelo pelo próprio estudante simboliza uma maneira moderna de ensinar em sala de aula, vincular prazer e criar ambientes interativos e dinâmicos de ensino-aprendizagem, engajando os estudantes por meio de desafios e curiosidades que proporcionam uma condição de muita concentração e comprometimento. (Matos, 2009; Souza, Faria, 2011).

Os materiais didáticos são vistos como ferramentas atraentes e apropriadas na prática docente em face da abordagem de conteúdos que se apresentam de difícil compreensão pelos estudantes. Dessa forma, a apropriação e a aprendizagem de conceitos, processos e conteúdos são favorecidos quando ocorre concretização em uma atividade lúdica.

Conhecendo a maioria das escola públicas do Brasil, fica evidente que estas não apresentam uma variedade de recursos e materiais didáticos disponíveis. Portanto, faz-se indispensável buscar possibilidades aplicáveis para executar metodologias que proporcionem aos estudantes um aprendizado mais significativo (Delizoicov et al., 2002). 
Dessa forma, o uso de modelos didáticos pode ser empregado no processo de ensino aprendizagem como método eficaz de trabalhar o conteúdo, em especial com objetivo emancipatório dos estudantes. De acordo com Harlen e Elstgeest (1992),

Um modelo didático é apenas uma maneira abreviada de indicar uma experiência de aprendizado na qual o aprendiz cria significado ou entendimento por meio de sua própria atividade mental e física. O que é fornecido como base para essa ação pode ser objetos ou materiais a serem investigados ou usados, problemas a serem resolvidos ou evidências a serem examinadas e discutidas (Harlen, Elstgeest, 1992, p. 3).

Ainda que haja um predomínio do uso de modelos didáticos em sala de aula, há relativamente baixos registros sobre sua efetividade que estejam além da caracterização dos procedimentos e dos participantes e a descrição da compreensão destes.

Trabalhar os processos da divisão celular em sala de aula não é uma tarefa fácil, pois requer que o professor encontre uma maneira de tornar o tema mais dinâmico e o estudante compreenda esse mecanismo. Associado ao agrupamento de deslocamentos citoplasmáticos em virtude dos filamentos microtubulares do citoesqueleto, existe uma grande quantidade de conceitos que dificulta ainda mais esse processo de ensino e aprendizagem, pois são moléculas de DNA, cromossomos, cromátides, homólogos, irmãs, replicação, microtúbulos, prófase, metáfase, anáfase, telófase, citocinese, leptóteno, zigóteno, paquíteno, diplóteno, diacinese, diploide, haploide, entre outros.

A divisão celular é um dos mecanismos mais dinâmicos que reestrutura toda a organização citoplasmática e nuclear para que suceda a impecável segregação do material genético e das organelas. Não há como entender o processo de maneira estática, apenas por ilustrações em sequência que descrevam o processo da forma tradicionalista, o que afeta a compreensão, por parte do aluno, de que todas as etapas estão associadas.

\section{Resultados e Discussão}

Os kits ficaram organizados em mesas diferentes, desta forma, no primeiro contato, os estudantes tiveram oportunidade de examinar os materiais, planejando sua elaboração de cada constituinte do processo de divisão celular. Nesse instante, foi perceptível comtemplar a animação e curiosidade durante a oficina. A curiosidade é uma capacidade que auxilia na geração de motivação inerente, em objeção às atividades tradicionais, de memorização ou mecânicas (Otero, 2006). O provimento de instrumentos de aprendizagem fomentado na curiosidade pode ampliar o engajamento dos estudantes ao trabalho e aumentar seus conhecimentos científicos (Otero, 2006; Vázquez, Manassero, 2008).

Por meio da análise dos resultados, foi possível observar elementos positivos e negativos na oficina. Um elemento positivo foi a facilidade de elaboração e aquisição dos materiais básicos para desenvolvimento da oficia. Levando em conta a oferta de recursos financeiros da rede pública de educação básica no Brasil, usar materiais de baixo custo ou até mesmo reciclados pode ser um modo de escolha para a aplicação desta estratégia didática em diferentes conjunturas. Outro aspecto positivo constatado que oportunizou a aplicação faz referência aos modelos produzidos das estruturas celulares envolvidas no processo de divisão celular, que estão bem semelhantes das representações simbólicas utilizadas no ensino médio, facilitado a identificação do modelo com o conteúdo das literaturas. As estruturas celulares implicadas na construção dos modelos didáticos foram facilmente construídas pelos estudantes.

No decorrer da oficina, os estudantes manifestaram aquisição de sociabilidade, interação em grupo e afetividade. Nessa prática, os estudantes puderam empregar o conhecimento teórico na construção das fases da divisão celular. Com relação ao ensino, a oficina possibilitou ao professor trabalhar de forma lúdica e interativa, transformando o tema em algo mais compreensível para o estante. Atividades práticas não apenas contribuem com a construção da aprendizagem, mas também 
oportunizam uma experiência mais agradável no processo de ensino e aprendizagem tanto para os estudantes quanto para os professores (Martínez et al., 2018; Bellocchi et al., 2014).

A grande dificuldade identificada na aplicação da oficina diz respeito ao tempo a ser concedido para que os estudantes preparassem e construíssem o processo. Mesmo desenvolvendo o trabalho em grupo, com segmentação de tarefas na preparação e desenvolvimento dos integrantes, o tempo empregado foi grande, o que se configura como um empecilho para o professor de Biologia, que detêm poucas aulas por semana para lecionar um currículo extenso.

Através de discussões produzidas, tendo o professor como mediador, os grupos foram realizando argumentações no sentido de aprofundar conceitos mencionados que são importantes para a representação da divisão com o uso do material (ciclo celular, mitose, replicação do DNA, cromatina, cromossomos homólogos, cromátides irmãs, diploidia, centrômero, microtúbulos, entre outros). Foi possível a representação de todo material genético humano devido à usabilidade do material disponibilizado aos estudantes.

A princípio, os grupos construíram as representações das moléculas e sua nomenclatura (DNA, DNA replicado, diferentes tipos de cromossomos - metacêntricos, submetacêntricos, acrocêntrico ou telocêntrico -, cromátides-irmãs, par de homólogos, entre outros). Essa primeira etapa possibilitou que os grupos entendessem as alternativas de uso e construção do material fornecido, aliando-as aos conceitos discutidos.

Após a preparação dos materiais pelos grupos e conforme iam construindo os modelos da mitose através das fases das divisões celulares, os estudantes percebiam a condensação dos cromossomos dentro do núcleo celular: a membrana nuclear se desfaz, o nucléolo desaparece e os centríolos migram para os polos da célula, configurando a prófase. Assim, eles compreendiam que o momento da divisão celular no qual os cromossomos são visíveis ao microscópio e ao centro da célula caracteriza a metáfase, e a relação das fibras do fuso mitótico com o deslocamento dos cromossomos para os polos da célula a anáfase. Além disso, os estudantes puderam perceber que na telófase a carioteca se forma novamente, os nucléolos reaparecem e os cromossomos descondensam, formando dois núcleos iguais ao inicial.

Todas as representações das estruturas e fases da mitose foram montadas, considerando elementos como citoplasma, envoltório nuclear e microtúbulos. A construção foi feita num ambiente amplo (mesa, bancada, refeitório ou no chão da sala de aula) de maneira que os estudantes ficassem à vontade. O professor auxiliou os grupos durante toda a atividade, mas sempre no papel de mediador, deixando que os estudantes fossem protagonistas. No decorrer da construção das fases da divisão celular, os estudantes tiveram a oportunidade de concretizar as discussões e analisar as ideias que surgiram a partir de seus questionamentos.

Durante a construção dos modelos, verificou-se que grande parte dos estudantes não encontrou dificuldade na oficina, bem como percebeu-se um vínculo entre os conceitos e as teorias ministradas em aulas anteriores. Além disso, os dados apresentam que os estudantes entenderam o assunto proposto. Porém, o principal obstáculo apresentado pelos estudantes foi empregar a terminologia científica e organização das etapas:

E. 9: "Senti dificuldade nos conceitos, tem palavras complicadas na genética, é difícil saber o que quer dizer essas palavras."

E. 27: "Fiquei com dúvida em montar as fases e as partes da célula, mas conversamos em grupos trocamos informações e conseguimos construir as fases das divisões celulares.

Após a construção da fases da mitose, os grupos articularam argumentações, discussões e promoveram a interação do conhecimento. A próxima etapa era a meiose: como ocorria em duas etapas, e os eventos de cada uma delas. A apropriação de conteúdo foi aos poucos se concretizando, à proporção que os estudantes debatiam ideias e dúvidas com os colegas de grupo. Notou-se que os estudantes que apresentavam mais segurança do processo ajudavam os que mostravam alguma dúvida, com 
relação ao conteúdo, realizando questionamentos, algumas vezes até mesmo para o professor. Assim, foi-se fortalecendo a criatividade ao trabalhar com uma temática que é abstrata por ser de nível celular, mas proporcionou aos estudantes uma visão particular sobre o tema, como pode ser percebido nos relatos:

E. 2: "Foi muito interessante em poder aprender e entender o assunto, se divertir aprendendo as atividades."

E. 17: "Fiquei bem surpresa pois tive um pouco de dificuldade em entender sobre mitose e meiose, e com essa atividade em grupo consegui aprender na prática como era bem simples."

E. 30: "Achei interessante e diferente, pois não tínhamos esse tipo de aula. Estávamos em grupo e isso ajudou muito. Foi fácil porque tinha oportunidade de conversar com os colegas e com o professor e assim aprender mais. Separamos as tarefas e conhecimento ficou fácil e rápido para construir as fases da mitose e meiose."

Em todos os grupos, os objetivos foram atingidos, pois possibilitaram aos estudantes uma visão ampla das fases da mitose e meiose, bem como as etapas de cada uma, a função das estruturas envolvidas na divisão (desenvolvimento do fuso acromático, carioteca, nucléolo, centríolo e cromátides dos cromossomos) e compreensão das diferenças de cada tipo de divisão celular, de maneira lúdica, motivando a curiosidade e concepção dos estudantes.

Figura 2: Registros das produções dos grupos na oficina.

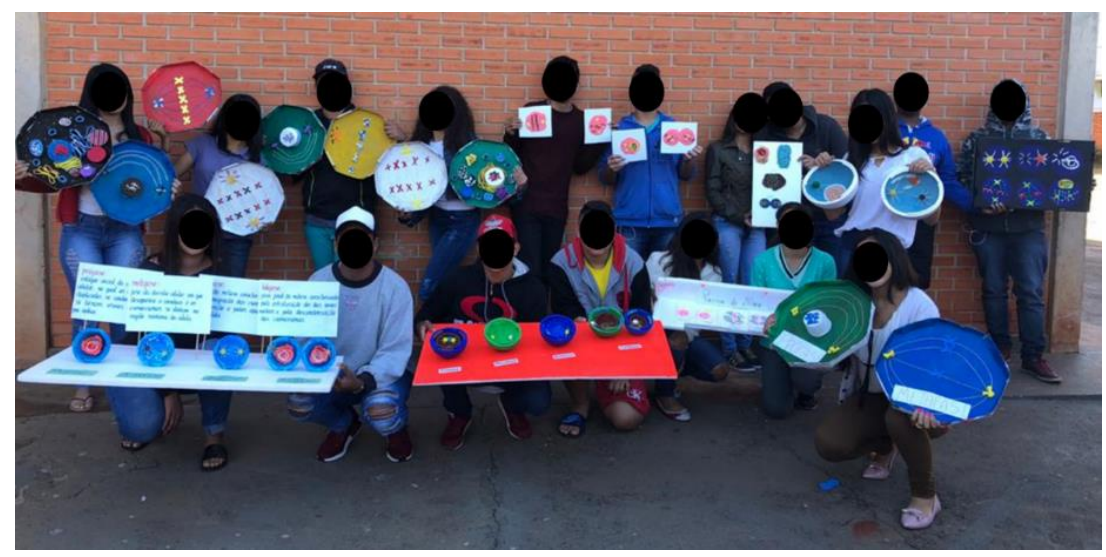

Fonte: Autor (2021).

Quanto à produção dos estudantes, dois grupos construíram os oito eventos da meiose, prófase I, metáfase I, anáfase I, telófase I, prófase II, metáfase II, anáfase II e telófase II; os demais só representaram os eventos da meiose I, que são semelhantes aos da mitose. Os trabalhos dos grupos 1, 2 e 3 nominaram todas as estruturas celulares envolvidas nas divisões. Os pares de cromossomos homólogos das representações estão em contato entre as cromátides homólogas (quiasmas) de forma correta e com as cores padronizadas, além de não terem sido identificados enganos no fenômeno de crossing over ou permutação (Figura 3ab).

Os estudantes, auxiliados pelo professor e com maior bagagem de conhecimentos, reconstruíram a meiose com a inserção da permuta (usaram massa de modelar para representar o complexo sinaptonêmico) e segregação independente dos homólogos. É importante salientar que dois grupos utilizaram conjuntos iguais (mesmo padrão de cor materno/paterno), o que deu oportunidade de comparar a variabilidade genética produzida. 
Figura 3: Registros dos grupos na oficina; a) registro do grupo 2 e b) registro do grupo 1.

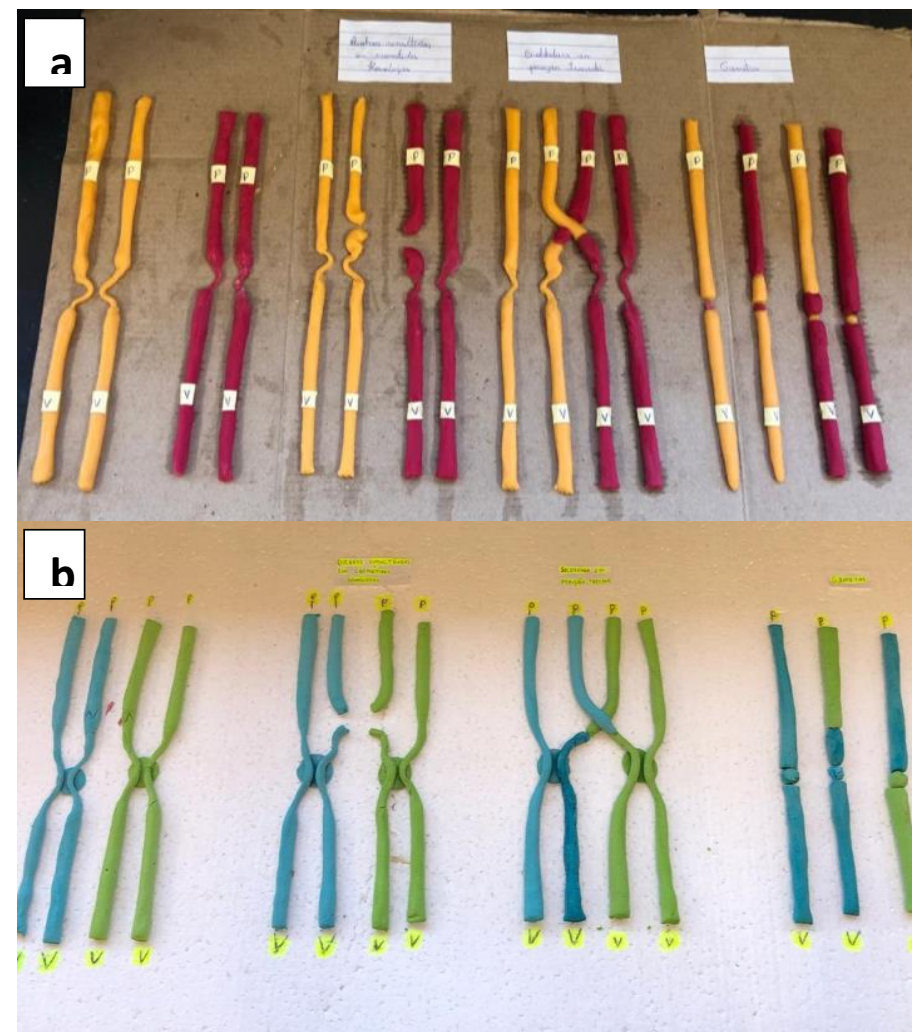

Fonte: Autor (2021).

Ao elaborarem as fases da meiose, foi possível construir o conceito de haploidia. Os estudantes representaram o processo da meiose, tendo como principal evento a separação de cromossomos homólogos e, posteriormente, das cromátides irmãs. Os estudantes entenderam os mecanismos da variabilidade genética (presente na prófase I e anáfase I), compreenderam a permuta entre os cromossomos homólogos e segregação independente dos cromossomos homólogos. As fases da meiose são, em geral, consideradas muito abstratas e recebidas com muita dificuldade pelos estudantes. Dessa forma, ao elaborarem inicialmente os mecanismos e em seguida acrescentar a variabilidade genética, assim como as etapas da prófase I, foi possível materializar cada conceito de maneira significativa.

Com o manuseio do material, cada grupo teve a oportunidade de refletir sobre as fases da meiose ao mesmo tempo em que construíam as probabilidades de arranjo para chegarem na construção da haploidia. Novamente, o professor teve papel de mediador, contribuindo com ferramentas conceituais que possibilitavam aos alunos a investigação dos questionamentos que surgiam.

A maioria das produções apresentaram padronização das cores dos cromossomos, porém os grupos que não sinalizaram esse alinhamento construíram as cromátides de forma a deixar entender que houve a formação de novas combinações gênicas, conforme pode ser observado na Figura 4. Essas novas combinações gênicas permitem a formação de gametas diferentes em um mesmo individuo, gerando diversidade dos seres vivos e sendo, portanto, um importante fator evolutivo. Dessa forma, foi possível constatar que todos os registros representam os principais eventos das divisões celulares. 
Figura 4: Registros dos grupos na oficina Fonte:

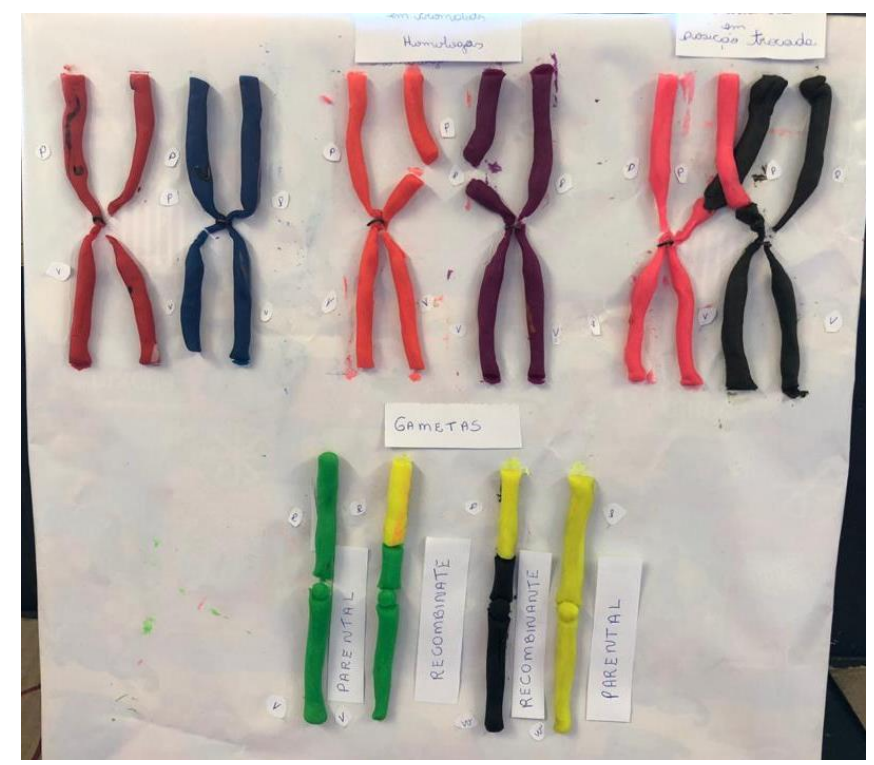

Fonte: Autor (2021).

A interfase (G1, S e G2) foi representada por todos os grupos, exceto o grupo 4. Observou-se, também, que o grupo 4 não representou a citocinese da meiose nos seus registros.

Os resultados analisados por meio das construções didáticas dos estudantes demonstram a necessidade do uso de metodologias práticas com o intuito de alcançar uma melhor aprendizagem em sala de aula. As observações corroboram com pesquisas anteriores que demostram que o ensino a partir de metodologias práticas constitui uma forma de melhorar a aprendizagem, possibilitando construções cognitivas de temáticas mais abstratas (Gabel, 1993; Noh, Scharmann, 1997; Sanger, 2000; Martínez et al., 2018; Wade-Jaimes et al., 2018; Baldwin, Orgill, 2019; Silva, 2021). A oficina proporcionou a apropriação do conteúdo abordado, assim como incentivou a criatividade dos estudantes ao trabalhar com um tema que é abstrato por ser de nível celular, proporcionando-lhes uma ótica mais concreta sobre a temática.

Por meio da pesquisa apresentada, pode-se deduzir que a aplicação das atividades práticas no Ensino de Genética é um método que vem colaborar com o processo de ensino e aprendizagem e que concepções externas têm potencialidade de auxiliar a aprendizagem dos estudantes (Stieff, 2016). De acordo com Mayer (2003), o conhecimento científico é assimilado com mais intensidade quando os estudantes não estão com sobrecarga em estado de memória visual e/ou auditiva. Porém, é importante destacar que, em práticas referentes às representações externas, como a aplicada nesta oficina, devem ser levados em conta os princípios da teoria Cognitiva da Aprendizagem por Multimídia (Mayer, 2003).

Ao serem indagados sobre a ação da oficina na aprendizagem e assimilação do processo de divisão celular, todos os estudantes responderam que a atividade pedagógica melhorou o processo de aprendizagem. As principais justificativas apontadas nas afirmações foram: o aspecto da atividade associar teoria e prática, possibilitando fácil compreensão do conteúdo; uma prática lúdica e prazerosa; tornar mais concreta a representação das estruturas do processo de divisão celular; a criatividade em comparação às metodologias empregadas pelos professores na abordagem desse tema.

E. 10: "Com essa atividade facilitou muito meu aprendizado, tive algumas dúvidas sobre como acontecia divisão celular e depois da oficina consegui fazer todas as atividades com facilidade."

E. 18: "Ajudou muito no aprendizado, para entender mais fácil a matéria."

E. 24: "Facilitou e muito, a oficina possibilitou a nós alunos o conhecimento teórico e também uma visão ampliada do meio microscópico de como o processo divisão celular realmente acontece." 
A atividade prática desenvolvida encontra-se embasada na literatura e na Base Nacional Comum Curricular. Entretanto, oficinas práticas como essas, muitas vezes, são negligenciadas na educação básica. Os motivos pelos quais os professores não empregam as aulas práticas são muitos, como a falta de recursos financeiros, falta de estrutura física e material, currículo denso e falta de tempo (Pagel et al., 2015; Lima et al., 2018). Interaminense (2019) afirma que, para os professores, essa modalidade didática é mais desconfortável e necessita ser mais bem planejada. Nesse sentido, a autora supracitada ainda assegura que muitos professores da rede pública ficam desanimados, pois precisam arcar com as despesas financeiras dessas práticas, o que se torna um empecilho. Porém, considera-se a necessidade dessas atividades práticas para o Ensino de Biologia, sobretudo o de Genética.

As aulas práticas possuem potencialidade pedagógica na assimilação do conhecimento científico pelos estudantes, como também contribuem para os professores em seu processo de ensino (Lima et al., 2018). As principais finalidades da aula prática, para a autora Krasilchik (2008), são: estimular e alimentar o interesse dos estudantes; interpretar conceitos básicos; despertar a habilidade de resolver problemas; engajar e aprimorar capacidades em investigações científicas. A autora Interaminense (2019) enfatiza as modalidades didáticas que envolvem práticas são necessárias na aquisição do conhecimento e impedem uma educação que provém da simples reprodução de conceitos que fogem do contexto dos estudantes.

Os relatos apresentados pelos estudantes também dispõem sobre justificativas de que a oficina foi uma modalidade pedagógica lúdica:

E. 4. "Foi muito interessante em poder aprender e se divertir aprendendo a atividades."

E. 22. "Foi divertido construir os modelos para fazer os processos de divisão celular, ajudou muito a aprender o conteúdo."

E. 31. "Proporcionou uma aprendizagem de maneira prática que fixamos o conteúdo e ao mesmo tempo divertida de se aprender."

Os resultados indicam uma tendência do lúdico aplicado como estratégia didática, da mesma forma que colabora para uma melhor interação dos estudantes por meio da socialização em grupo, além de tornar a aula mais compreensiva e agradável. De acordo com Pinto e Tavares (2010):

O lúdico desempenha um papel vital na aprendizagem, pois através desta prática os sujeitos buscam conhecimento do próprio corpo, resgatam experiências pessoais, valores, conceitos buscam soluções diante dos problemas e tem a percepção de si mesmo como parte integrante no processo de construção de sua aprendizagem, que resulta numa nova dinâmica de ação, possibilitando uma construção significativa (Pinto, Tavares, 2010, p. 233).

Conforme as análises citadas, é plausível concordar com Lima et al., (2018), ao afirmarem que as aulas práticas transformam o conteúdo em algo mais dinâmico, incentivador e próximo do cotidiano dos estudantes. As atividades práticas apresentam um aspecto lúdico e tem a capacidade de envolver a competência do aprendizado, trabalham como meio de atrair o estudante no tema abordado, promovendo, portanto, o pensamento científico, a cognição e liberdade intelectual (Pagel et al., 2015). As práticas lúdicas que apresentam objetivos e metodologias bem delineadas possuem lugar de relevância na educação escolar (Rocha et al., 2017). Os profissionais da área educacional podem adotar a modalidade prática de atividades lúdicas de maneira a aumentar a assimilação do conteúdo por parte dos estudantes e proporcionar motivação e engajamento nestes.

Os estudantes também mencionaram que a atividade possibilitou uma metodologia mais concreta para abordagem do

tema: 
E. 6. "Bastante benéfica a minha formação, a oficina permitiu uma análise da realidade de cada grupo do conteúdo disposto, além de permitir o intercâmbio de experiências, favorecendo ainda mais na construção de aprendizado sólido do tema apresentado (mitose e meiose)."

E. 14. "A forma em que foram construídos, proporcionando uma visão macro de um processo tão importante que é a divisão celular."

E. 29. "Facilitou, porque como nós fizemos, pesquisamos, a aprendizagem foi melhor por entender como funcionava de forma mais concreta."

Na opinião dos estudantes, o processo de divisão das células pode ser algo abstrato. Com a construção dos modelos didáticos, foi oportunizada uma ferramenta que, simultaneamente, possibilita a aprendizagem de forma lúdica como permite um menor nível de abstração. A oficina de construção de divisões celulares possibilitou aprender com interatividade uma temática tradicionalmente tratada de modo exclusivamente teórico, visto que diversos estudantes argumentaram que a oficina foi uma abordagem diferente em comparação às empregadas pelos professores ao trabalharem esse assunto.

E. 19: “A atividade prática facilitou muito. Porque com exemplos ficou mais fácil para entender o que estava sendo ensinado. Foi muito interessante aulas desse jeito, outras formas de ensinar e aprender."

E. 21: "Achei interessante e diferente, pois não tínhamos esse tipo de aula."

E. 28: "A oficina melhorou muito o entendimento, porque com esses aprendizados ficaram mais fácil pra entender a matéria, foi mais atrativa e diferente das aulas normais."

Outras descrições similares aos dos estudantes E. 19, E. 21 e E. 28 apontam que o Ensino de Biologia ainda ocorre de forma descritiva, abstrata e mecânica, além de ser marcado pela transmissão unidirecional do conhecimento, associado à carência de diversificação metodológica, acarretando a perda do entusiasmo do estudante. Krasilchik (2008) destaca que essa maneira de ensinar impede as várias formas de aprender, visto que cada circunstância necessita de uma solução específica, além de que a diversidade de atividades e de metodologias podem provocar o interesse dos estudantes, observadas as diferenças individuais. Diante disso, variar as estratégias de ensino é necessário, não apenas para aumentar as possibilidades de aprendizagens, mas também como formas de ampliar as opções para que elas se realizem, contribuindo na superação das dificuldades.

Ao requisitar que os estudantes argumentassem sobre suas experiências na participação da oficina de construção dos modelos didáticos, todos os relatos confirmam contentamento e ainda demostram que a atividade ofereceu construção de conhecimento, estimulando o interesse. Algumas das argumentações pelos estudantes seguem abaixo:

E. 5: Facilitou muito a entender o processo de divisão celular, ainda mais sobre a meiose que é mais complicada. Com a prática foi reforçando ainda mais o conteúdo de maneira divertia de fácil. Fizemos pesquisas e o aprendizado foi melhor."

E. 32: "Ficou muito mais fácil de aprender, porque como nós fizemos, pesquisamos, a aprendizagem foi melhor de entender como funcionava a mitose e a meiose."

Por meio de algumas respostas dos estudantes e das observações realizadas, percebe-se que a aplicação da prática em grupo foi um aspecto essencial para que as indecisões sobre a temática fossem esclarecidas, além do compartilhamento de informações e conhecimento entre os estudantes.

E. 1: "Foi ótimo fazer a prática em grupo, pois que cada aluno tive a chance de esclarecer suas dúvidas e aprender melhor com a opinião dos demais colegas."

E. 12: "Muito boa a atividade ser em grupos, porque cada um tem um pensamento e quando junta os grupo acabar que as atividades saiam melhores."

E. 20: "Na minha opinião a atividade em grupo é bastante eficaz, fazendo com que os alunos troque experiências e conhecimentos entre as equipes gerando ainda mais uma integração do conhecimento." 
E. 26: "Foi bem melhor em grupo, pelo fato que um tirava a dúvida que o outro tinha."

Conforme as respostas, os estudantes destacaram que a atividade em grupo possibilitou um processo de construção de aprendizagem por meio da socialização. Eles valoram as concepções empregadas nas expressões "esclarecer suas dúvidas e aprender melhor", "cada um tem um pensamento", "os alunos trocam experiências e conhecimentos entre as equipes", "tirava a dúvida que o outro tinha", entre outras. A formação de grupos fortalece o aprendizado social entre os participantes, proporcionando que os estudantes com carências parecidas possam se ajudar e criar soluções (Liebmann, 2000). O trabalho em grupo, por sua vez, possibilita que ocorra uma socialização entre os envolvidos, disponibilizando, dessa forma, novas descobertas e conhecimentos por meio da coletividade (Sousa et al., 2010). A inclusão de estratégias por meio de grupos deve estar presente na conjuntura do ensino para que tenha atuação ativa de todos os estudantes, fazendo com que sejam protagonistas na construção dos conhecimentos (Cirineu et al., 2016; Sasseron, 2019). Em síntese, o ensino produzido por meio da oficina dispõe-se como uma abordagem favorável para o ensino de divisão celular.

Dessa maneira, acredita-se que as análises dispostas podem auxiliar como estimuladoras os professores para que eles utilizem essa abordagem de ensino em sala de aula.

\section{Considerações Finais}

Por intermédio da oficina de construção de modelos didáticos de divisões celulares, desenvolveu-se uma ferramenta pedagógica em oposição a uma educação tradicional, que é centrada no professor como mantenedor de todo conhecimento e o estudante é visto como mero reservatório inerte de informações. A construção e execução da prática foram apoiadas no uso de materiais de fácil acesso e de baixo custo financeiro, levando em conta as dificuldades da educação pública brasileira.

A oficina foi uma atividade que possibilitou relacionar a teoria e prática, sendo fundamental para estimular a curiosidade intelectual e científica, permitindo o tema de divisão celular mais compreensível à percepção dos estudantes de forma lúdica, interativa e motivacional. A colaboração foi proporcionada pelos modelos construídos simbolicamente pelos próprios estudantes, que assumiram o papel de protagonistas de sua aprendizagem, interagindo com o conteúdo e favorecendo o processo da apropriação do conhecimento. Ainda que os resultados qualitativos não possibilitem dizer que a oficina proporciona aprendizado, os resultados qualitativos indicam que a oficina colaborou para tornar a aprendizagem dos conceitos em Genética mais motivadora e eficiente, criando a formação de um modelo mental de divisão celular pelos estudantes.

Por meio dos resultados dispostos, identificam-se as vantagens possibilitadas pela atividade didática bem como adverte-se para suas deficiências. Pode-se induzir que a oficina foi atestada como uma ferramenta didática a ser aplicada em sala de aula, o que demanda autonomia do professor para utilizá-la ou adaptá-la de acordo com seu contexto educacional. É possível planejar e executar esta oficina sem a necessidade de um laboratório ou de materiais complexos. Os modelos didáticos não necessitam ser ferramentas para revisar o conteúdo, pois são capazes de ser ferramentas para a própria construção do conhecimento. Dessa forma, considera-se que oficina proposta tem capacidade de colaborar como ferramenta metodológica dentro das salas de aula para auxiliar os professores, pois é uma prática descomplicada, acessível, de fácil entendimento e que apresentou grande aceitação por parte dos estudantes.

Novos estudos devem possibilitar mais aprofundamento no debate vinculados ao uso de novas estratégias de ensino, bem como para uma constante reflexão dos professores quanto à sua prática pedagógica, motivando a renovação do ambiente de ensino e aprendizagem. 


\section{Referências}

Antunes, A.M. \& Sabóia-Morais, S.M.T. (2010). O jogo Educação e Saúde: uma proposta de mediação pedagógica no ensino de Ciências. Experiências em Ensino de Ciências. 5(2), 55-70.

Ausubel, D.P. (1980). Psicologia educacional. Tradução: Eva Nick. Rio de Janeiro: Editora Intramericana Ltda.

Ayuso, G. \& Bannet, E. (2002). Alternativas a la enseñanza de la genética em educación secundaria. Enseñanza de las Ciencias. $20(1), 133-157$.

Bahar, M. \& Johnstone. H. (1999). Revisiting learning difficulties in biology. Journal Biology Education. 33(2).

Baldwin, N. \& Orgill, M. (2019). Relationship between teaching assistants' perceptions of student learning challengesand their use of external representations when teaching acid-base titrations in introductory chemistrylaboratory courses. Chemistry Education Research and Practice. 20(4), 821-836.

Banet, E. \& Ayuso, G.E. (1995). Introduccion a la genética em la ensenanza secundaria y bachillerato. Ensenanza de las Ciências. $373-407$.

Bardin, L. (2011). Content analysis. São Paulo: Edições.

Barni, G. S. (2010). A importância e o sentido de estudar Genética para estudantes do terceiro ano do Ensino Médio em uma escola da rede estadual de ensino em Gaspar (SC). Dissertação (Programa de Mestrado Profissional em Ciências Naturais e Matemática da Universidade Regional de Blumenau) FURB, Blumenau.

Bellocchi, A.; Ritchie, S. M.; Tobin, K.; King, D.; Sandhu, M. \& Henderson, S. (2014). Emotional climate and high-qualitylearning experiences in science teacher education. J. Res. Sci. Teach. 51, 1301-1325.

Belmiro, M. S. \& Barros, M. D. M. (2017). Ensino de Genética no Ensino Médio: uma análise estatística das concepções prévias de estudantes préuniversitários. Revista Práxix. 9(17) 95-102.

Brasil. Base Nacional Comum Curricular - BNCC. (2018). Ministério da educação.

Brito, D. R. S. (2018). Ensino de Genética: proposta para o ensino superior. Dissertação de Mestrado Profissional em Ensino de Ciências, pelo Programa de Pós-Graduação em Ensino de Ciências da Universidade de Brasília. Brasília.

Brito, M. R. F. (1996). O ensino e a formação de conceitos na sala de aula. Psicologia na Educação: articulação entre pesquisa, formação e prática pedagógica. 5, 73-93. Rio de Janeiro: Associação Nacional de Pesquisa e Pós-Graduação em Psicologia.

Broman, K.; Ekborg M. \& Johnels J. (2011). Chemistry in crisis? Perspectives on teaching and learning chemistry in Swedish upper secondary schools. Nordina. 7(1), 43-53.

Bugallo. (1995). LaDidática de la Genética: revisión bibliográfica. Ensenñanza de las Ciências. 13(3), 379-385.

Cabrera, W. B. (2007). A ludicidade para o ensino médio na disciplina de Biologia: contribuições ao processo de aprendizagem em conformidade com os pressupostos teóricos da Aprendizagem Significativa. Dissertação de Mestrado em Ensino de Ciências e Educação Matemática. Universidade Estadual de Londrina, Londrina.

Campos, L. M. L.; Bortoloto, T. M. \& Felicio, A. K. C. (2008). A produção de jogos didáticos para o ensino de ciências e biologia: uma proposta para favorecer a aprendizagem. UNESP - SP.

Cid, M. \& Neto, A. J. (2005). Dificuldades de aprendizagem e conhecimento pedagógico: o caso da Genética. Ensenanzas de las ciências, número extra, VII Congresso.

Cirineu, C. T, Fiorati, R. C. \& Assad, F. B. (2016). A utilização de técnicas de grupo em sala de aula: contribuições paraoprocesso de ensino-aprendizagem na graduação em terapia ocupacional. Revista de Terapia Ocupacionalda Universidade de São Paulo. 27(3), 349 -354.

Corrêa, D. M. V. B. \& Silva Junior, E. F. (2010). Ciência vai à escola: o Lúdico na Educação em Ciências. Universidade Federal do Paraná - Museu de Ciências Naturais.

De Campos Júnior, E. O.; Pereira, B. B.; Luiz, D. P.; Moreira-Neto, J. F.; Bonetti, A. M. \& Kerr, W. E. (2009). Sistema sanguíneo sem mistério: uma proposta alternativa. Revista Genética na Escola - SBG. 3(3), 7-9.

Delizoiciv, D.; Angotti, J.A. \& Pernambuco, M. M. (2002). Ensino de ciências: fundamentos e métodos. São Paulo: Cortez.

Duré, R. C.; Andrade, M. J. D. De \& Abílio, F. J. P. (2018). Ensino de biologia e contextualização do conteúdo: quais temas o aluno de ensino médio relaciona com o seu cotidiano?. Experiências em Ensino de Ciências. 13(1), 259-272.

Ferreira, P. \& Justi, R. (2005). Atividades de construção de modelos e ações envolvidas. V Encontro Nacional de Pesquisa em Educação em Ciências. ENPEC.

Francisco, G. C. B. (2005). O ensino de Genética: uma abordagem a partir dos estudos sociais da ciência e da tecnologia (ESTC). Dissertação de Mestrado (Programa de Pós-Graduação, Mestrado em Educação). FURB.

Franzolin, F. \& Bizzo, N. (2012). Conteúdos de genética básicos para a formação de cidadãos críticos no ensino médio segundo professores e docentes: em comparação com o defendido na literatura. IX ANPED SUL: Seminário de Pesquisa em Educação da Região Sul.

Gabel, D. L. (1993). Use of the particle nature of matter in developing conceptual understanding, J. Chem. Educ. 70(3), $193-194$.

Giacoia, L. R. D.; Bortolozzi, J \& Caldeira, A. M. A. (2014). Concluintes do ensino médio e o conhecimento de genética. Rev. Cereus. 6(1), 157-174. 
Giordan, A. \& Vecchi, G. (1996). As origens do saber - das concepções dos aprendentes aos conceitos científicos. Porto Alegre: Artes Médicas. 2.

Goldbach, T. \& Macedo, A. G. A. (2008). Produção científica e saberes escolares na área de ensino de Genética: olhares e tendências. In: Jornadas LatinoAmericanas de estudos sociais das Ciências e das Tecnologias. Rio de Janeiro.

Harlen W. \& Elstgeest J. (1992). Sourcebook for science in the primary school: A Workshop approach to teacher education. Paris, France: UNESCO.

Interaminense, B. D. K. S. (2019). A Importância das aulas práticas no ensino da Biologia: Uma MetodologiaInterativa/The Importance of practical lessons in the teaching of Biology: An Interactive Methodology. Revista de Psicologia. 13(45), 342-354.

Jann, P. N. \& Leite, M. F. (2010). Jogo do DNA: um instrumento pedagógico para o ensino de Ciências e Biologia. Ciência \& Cognição. 15(1).

Justina, L. A. D. \& Ferla, M. R. (2006). A utilização de modelos didáticos no ensino de Genética - exemplo de representação de compactação de DNA eucarioto. Arquivos do Mundi, Maringá - Paraná. 10(2), 35-40.

Klautau-Guimarães, N.; Aurora, A.; Dulce, D.; Silviene, S. \& Helena, H.C.A. (2008). A relação entre herança genética, reprodução e meiose: um estudo das concepções de estudantes universitários do Brasil e Portugal. VIII Congresso Internacional sobre investigación em la Didáctica de las Ciencias. Barcelona.

Krasilchik, M. (2008). Prática de Ensino de Biologia. 4a. ed. São Paulo, SP: Edusp.

Krasilchik, M. (2004). Prática de ensino de biologia. Edusp.

Ladelfo, J.; Lisboa, C. P.; Pizzato, M. C. (2012). Pesquisa e análise das concepções prévias de alunos do ensino médio sobre o tema material genético. 13a Mostra de Pesquisa, ensino e extensão Instituto Federal de Educação, Ciência e Tecnologia do Rio Grande do Sul. Porto Alegre.

Lewis, J. \& Wood-Robinson, C. (2000). Genes, chro-mosomes, cell division and inheritance - do students see any relationship? International Journal os Science Education, London. 22(2), 177-195.

Liebmann, M. (2000). Exercícios de arte para grupos. Summus Editorial.

Lima, L. P. S.; Lima, J. F. \& Amorim, T. V. (2018). Aulas práticas para o ensino de Biologia: contribuições elimitações no ensino médio. Revista de Ensino de Biologia da SBEnBio. 11(1), 36-54.

Lopes, K. D. \& Silva, C.C. (2018). Percepção de alunos no Ensino Médio quanto aos conceitos fundamentais de Genética básica: um estudo de caso. Rev. Ens. Educ. Cienc. Human. Londrina, PR. 19(1) 2-9.

Lucchini, L. M. (2009). Ecorrecreação: Uma proposta metodológica lúdica de ensino de Ciências Naturais. Dissertação de Mestrado em Educação. Centro Universitário La Salle, Canoas.

Luciano, K. M. F. (2017). O uso de material concreto no ensino e aprendizagem da matemática. 11.

Luckesi, C. (2014). Ludicidade e formação do educador. Revista Entreideias, Salvador. 3(2), 13-23.

Manprim, M. I. L. L. (2007). A implementação ou não de atividades experimentais em biologia no ensino médio e as relações com o saber profissional, baseadas numa leitura de Charlot. In: VI Encontro Nacional de Pesquisa em Educação em Ciências, Florianópolis.

Martinez, E. R. M.; Fujihara, R.T. \& Martins, C. (2008). Show da Genética: um jogo interativo, para o ensino de Genética. Genética na Escola.

Martínez, G.; Naranjo, F. L. \& Mateos, M, Sánchez, J. (2018). Recreational Experiences for Teaching Basic ScientificConcepts in Primary Education: The Case of Density and Pressure. Eurasia J. Math. Sci. Technol. 14, 1-16.

Matos, C. H. C. (2009). Utilização de Modelos Didáticos no Ensino de Entomologia. Revista de Biologia e Ciências da Terra. 9(1), $19-23$.

Mayer R. E. (2003). The promise of multimedia learning: using the same instructional design methods acrossdifferent media, Learn. Instruct. 13(2), 125-139.

Melo, J. R. \& Carmo, E. M. (2009). Investigações sobre o ensino de genética e biologia molecular no ensino médio brasileiro: reflexões sobre as publicações científicas. Ciência\&Educação. 15(3), 593-611.

Neves, M. A. \& Neves, M. L. R. C. (2016). A Biologia Forense no jogo didático: uma ferramenta motivacional para o Ensino de Genética em uma abordagem investigativa. Revista da Sociedade Brasileira do Ensino de Biologia. 9.

Noh, T. \& Scharmann, L. C. (1997). Instructional influence of a molecular-level pictorial presentation of matter onstudents' conceptions and problem-solving ability, J. Res. Sci. Teach. 34(2), 199-217.

Otero, M. R. (2006). Emociones, sentimientos y razonamientos en Didáctica de las Ciencias. Rev. Electrónica Investig.Educ. Cienc. 1, $24-53$.

Pagel, U. R.; Campos, L. M. \& Batitucci, M. D. C. P. (2015). Metodologias e práticas docentes: uma reflexão acercada contribuição das aulas práticas no processo de ensino-aprendizagem de biologia. Rev. Experiências em Ensino de Ciências. 10.

Pavan, O. H. (1998). Evoluindo genética: um jogo educativo. 1.ed. Campinas: Ed. Unicamp.

Pedrancini, V. D.; Corazza-Nunes, M. J.; Galuch, M. T. B.; Moreira, A. L. O. R. \& Ribeiro, A. C. (2007). Ensino e aprendizagem de biologia no ensino médio e a apropriação do saber científico e biotecnológico. Revista Electrónica de Enseñasza de las Ciencias. 6(2), $299-309$.

Pedroso, C. V. (2009). Jogos didáticos no ensino de Biologia: uma proposta metodológica baseada em módulo didático. EDUCERE. 
Research, Society and Development, v. 11, n. 1, e42411125116, 2022

(CC BY 4.0) | ISSN 2525-3409 | DOI: http://dx.doi.org/10.33448/rsd-v11i1.25116

Piaget, J. (1975). A formação do símbolo na criança: imitação, jogo e sonho, imagem e representação. Rio de Janeiro: Zahar.

Pinto, C. L. \& Tavares, H. M. (2010). O lúdico na aprendizagem: apreender e aprender. Revista da Católica, Uberlândia. 2(3), $226-235$.

Predebon, F. \& Del Pino, J. C. (2009). Investigações em Ensino de Ciências uma análise evolutiva de modelos didáticos associados às concepções didáticas de futuros professores de química envolvidos em um processo de intervenção formativa. 14(2), 237-254.

Rocha, N. C.; Vasconcelos, B.; Maia, J. C.; Gallão, M. I.; Rodrigues, D. A. M. \& Hissa, D. C. (2017). Jogo didático “sínteseproteica” para favorecer a aprendizagem de Biologia Celular. Experiências em Ensino de Ciências. 12(2), 129-137.

Rundgren S. \& Yao B. (2014). Visualization in research and science teachers' professional development. In Asia-Pacific Forum on Science Learning and Teaching. The Education University of Hong Kong, Department of Science and Environmental Studies. 15(2), 1-21.

Sanger, M. J. (2000). Using particulate drawings to determine and improve students' conceptions of puresubstances and mixtures, J. Chem. Educ; 77(6), 762766.

Sardinha, R.; Fonseca, M. \& Goldback, T. O que dizem os trabalhos dos Anais dos Encontros de Pesquisa em Ensino de Ciências sobre Ensino de Genética. Encontro Nacional de Pesquisa em Educação em Ciências, Florianópolis, 2009.

Sasseron, L. H. (2019). Sobre ensinar ciências, investigação e nosso papel na sociedade. Ciências e Educação. 25(3), 563-567.

Setúval, F. A. R. \& Bejarano, N. R. R. (2009). Modelos didáticos com conteúdo de genética e a sua importância na formação inicial de professores para o ensino de ciências e biologia. In: Encontro Nacional de pesquisa em Educação em Ciências, Florianópolis. Anais. Florianópolis: ABRAPEC. 7.

Silva, H. M. (2021). A Metodologia de Resolução de Problemas no Ensino da Genética. Scientia Generalis. 2(2), 1-13.

Silveira, L. F. S. (2008). Uma contribuição para o ensino de Genética. Dissertação (Mestrado em Ciências e Matemática). Universidade Católica do Rio Grande do Sul.

Sousa, D. L. M. D; Pinto, A. G. A \& Jorge, M. S. B. (2010). Tecnologia das relações e o cuidado do outro nas abordagensterapêuticas grupais do centro de atenção psicossocial de Fortaleza-Ceará. Texto \& Contexto-Enfermagem. 19(1), 147-154.

Souza, P. F. De \& Faria, J. C. N. De M. (2011). A construção e avaliação de modelos didáticos para o ensino de Ciências Morfológicas - uma proposta inclusiva e interativa. Enciclopédia Biosfera, Centro Científico Conhecer. 7(13), 1550-1561.

Stewart, J. (1982). Dificulties experienced by high school students when learning basic Mendelian Genetics. The American Biology Teacher. 2(44), 731-739.

Stieff, M.; Scopelitis, S.; Lira, M. E. \& Desutter, D. (2016). Improving representational competence with concrete models, Sci. Educ. 100(2), $344-363$.

Tarouco, L. M. R.; Roland, L. C.; Fabre, M. C. J. M. F. \& Konrath, M. L. P. (2004). Jogos Educacionais. CINTED - UFRGS. Novas Tecnologias na Educação. 2(1).

Temp, D. S. \& Bartholomei-Santos, M. L. (2018). O ensino de genética: a visão de professores de Biologia. Rev. Cient. Schola. 2(1), 83-95.

Varghese, J.; Minnie F \& Molly J. (2012). Impact of e-resources on learning in biochemistry: first-year medical students' perceptions. BMC Medical Education. 12(1), 1-9.

Vázquez, A. \& Manassero, M. A. (2008). El declive de las actitudes hacia la ciencia de los estudiantes: Un indicadorinquietante para la educación científica. REurEDC. 5, 274-29.

Vygotsky, L.S. (2003). Psicologia pedagógica. Trad.Claudia Schilling. Porto Alegre: Artmed, p.576.

Wade-Jaimes, K.; Demir, K. \& Qureshi, A. (2018). Modeling strategies enhanced by metacognitive tools in high schoolphysics to support student conceptual trajectories and understanding of electricity. Sci. Educ. 102, 711-743.

Zanon, D. A. V.; Guerreiro, M. A. S. \& Oliveira, R. C. (2008). Jogo didático Ludo Químico para o ensino de nomenclatura dos compostos orgânicos: projeto, produção, aplicação e avaliação. Ciência \& Cognição. 13(1), 72-81. 